\title{
ÖNKÉNTESEK SZERVEZÉSE KORONAVÍRUS IDEJÉN - A JÓZSEFVÁROSI KÖZÖSSÉGI RÉSZVÉTELI IRODA
} TAPASZTALATAI

\author{
BALÁZS-PIRI KATA ${ }^{1}$ - HEGYI DÓRA ${ }^{2}$ - HORVÁTH ÁDÁM ${ }^{3}$ -
}

UDVARHELYI TESSZA4 - JO URBAN ${ }^{5}$

DOI: https://doi.org/10.53585/OnkSzem.2021.2.98-109

\section{Absztrakt}

A koronavírus nagy kihívás elé állított mindenkit, aki önkéntesek szervezésével vagy közösségépítéssel foglalkozik. Egy ideig úgy éreztük, mintha elvesztettük volna az összes addig jól bevált eszközünket arra, hogy kapcsolatokat építsünk az emberek között. Szerencsére ez valójában nem volt így, és még a kötelező távolságtartás időszakában is számos lehetőség volt arra, hogy közösen dolgozzunk számunkra fontos ügyekért és közben az emberek közötti kapcsolatépítést is segítsük. Alább azokat a tapasztalatainkat foglaljuk össze, amiket a Józsefvárosi Önkormányzat Közösségi Részvételi Irodája munkatársai és önkéntesei szereztek a koronavírus-járvány idején a helyi lakóknak szervezett önkéntes segítségnyújtás kapcsán. A cikkben kitérünk az önkéntesek toborzásának, bevonásának, támogatásának és a munkájuk szervezésének gyakorlati részleteire, amely reményeink szerint hasznos lesz majd a pandémián túli életünkben, mind az önkormányzatok, mind pedig a civil szervezetek és az informális közösségek számára is.

Kulcsszavak: COVID-19 járvány, önkéntesség, Józsefvárosi Önkormányzat Közösségi Részvételi Iroda, önkéntes toborzás, önkéntes szervezés,

Organizing volunteers under the coronavirus pandemic - Experiences of the Józsefváros Office of Community Participation

KATA BALÁZS-PIRI - DÓRA HEGYI - ÁDÁM HORVÁTH - TESSZA UDVARHELYI - JO URBAN

\section{Abstract}

The coronavirus pandemic has presented all of us involved in the organizing and building of communities with great challenges. It felt as if we had lost all our previous tools to build relationships among people.

\footnotetext{
${ }^{1}$ Balázs-Piri Kata, rendezvényszervező, önkénteskoordinátor, Józsefvárosi Önkormányzat Közösségi Részvételi Iroda

${ }^{2}$ Hegyi Dóra, közgazdász, irodavezetö, Józsefvárosi Önkormányzat Ügyviteli Iroda

${ }^{3}$ Horváth Ádám, antikvárius, újságíró, önkéntes

${ }^{4}$ Udvarhelyi Tessza, kulturális antropológus, környezetpszichológus, irodavezetö, Józsefvárosi Önkormányzat Közösségi Részvételi Iroda

${ }_{5}^{5}$ Jo Urban, önkéntes
} 
Fortunately, this did not end up being the case in reality as there have been opportunities to work together for causes that are important for all of us while building of communities even at the time of social distancing. In our article we summarize the experiences we have gathered as staff members and volunteers of the Office of Community Participation at the municipality of the 8th district of Budapest under the coronavirus pandemic while organizing volunteers to support local residents in need of help. In the article we elaborate on the practical details of recruiting, involving, supporting volunteers and of the organization of their work, which data will hopefully be useful in our lives beyond the pandemic for municipalities, civil organizations, and informal communities.

Keywords: COVID-19 pandemic, volunteering, Józsefváros's Office of Community Participation, recruitment of volunteers, organizing volunteer activity,

\section{BEVEZETÉS - ÖNKÉNTESSÉG A JÓZSEFVÁROSI KÖZÖSSÉGI RÉSZVÉTELI IRODÁNÁL}

A Józsefvárosi Önkormányzat Polgármesteri Hivatalában a polgármesteri kabineten belül kialakított Közösségi Részvételi Iroda 2020. március 1-jén kezdte meg hivatalosan a munkáját. A Közösségi Részvételi Iroda célja a józsefvárosi közösségek erősítése és a helyi lakók bevonása a közös döntésekbe. Hiszünk abban, hogy közös tudással és érdemi párbeszéddel új, kreatív, hatékony és igazságos megoldásokat tudunk találni közös problémáinkra. Munkánk során a következő alapelvek megvalósításáért dolgozunk: közérthetőség, átláthatóság, akadálymentes hozzáférés, méltányosság és szolidaritás.

Annak érdekében, hogy megvalósuljon a józsefvárosiak korrekt, átlátható és hatékony tájékoztatása, ügyfélbarát tájékoztató felületeket és csatornákat alakítottunk ki és müködtetünk online és offline is. Feladatunk, hogy az önkormányzati folyamatok és döntések közérthetőek és átláthatóak legyenek. Munkánk során a Józsefvárosi Önkormányzat vezetését abban segítjük, hogy egyre több területen valósítson meg érdemi konzultációs folyamatokat az olyan fontos döntések előtt, amelyek a lakók életét jelentősen befolyásolják. Ezen kívül olyan eseményeket szervezünk, amelyek az önkormányzat és a helyi közösségek közötti párbeszéd színterei lehetnek, ideértve a közösségi fogadóórákat és közmeghallgatásokat is. Annak érdekében, hogy a helyi polgárok, civil szervezetek és az önkormányzat között egyre erősebb legyen az együttmúködés, olyan folyamatokat dolgozunk ki és felügyelünk, amelyek lehetővé teszik a közös döntéshozatalt, ideértve a részvételi költségvetést és a közösségi tervezést.

A Józsefvárosi Önkormányzat munkájának közvetlen segítésén túl a Közösségi Részvételi Iroda feladata a helyi közösségek, civil szervezetek és polgárok megerősítése a közösségfejlesztés és közösségszervezés eszközeivel. Az önkéntességet az aktív állampolgárság egy formájának tekintjük, így a koronavírus-járványtól függetlenül is folyamatosan lehetőséget biztosítunk a 
józsefvárosiaknak arra, hogy részt vegyenek az önkormányzat közösségfejlesztő, közösségszervező és segítő munkájában.

A koronavírus nagy kihívás elé állított mindenkit, akik emberek szervezésével vagy közösségépítéssel foglalkoznak. Egy ideig úgy érezhettük, hogy elveszítettük minden jól bevált eszközünket arra, hogy kapcsolatot építsünk az emberek között. Ezzel együtt Józsefvárosban a pandémia miatt még a korábbiaknál is nagyobb szükség volt arra, hogy az önkormányzat a saját erőforrásain túl a helyi lakókat is intenzíven bevonja a járvány miatt előállt szociális, mentális és közegészségügyi válsághelyzet megoldásába. A szükséghelyzet nagyon sok újításhoz vezetett az önkormányzat gyakorlatában és megalapozta a józsefvárosi önkéntesrendszer későbbi fejlesztését is. Alább azokat a gyakorlati tapasztalatainkat foglaljuk össze, amiket a Közösségi Részvételi Iroda munkatársai és a több mint 80 önkéntes szerzett a koronavírus-járvány idején a helyi lakóknak szervezett önkéntes segítségnyújtás kapcsán.

\section{AZ ÖNKÉNTESEK ONLINE SZERVEZÉSÉNEK ALAPELVEI A KORONAVÍRUS IDEJÉN}

\section{Önkéntesek toborzása}

Ahogyan a személyes munkában, az online szervezésben is fontos alaptétel, hogy az emberek akkor fognak hozzánk csatlakozni, ha hívjuk őket. Vagyis, ha szeretnénk, hogy új önkéntesek csatlakozzanak hozzánk vagy a régieket akarjuk aktivizálni, tegyünk közzé felhívást. Az, hogy ezt milyen körben tesszük (teljesen nyilvánosan, korlátozott körben, vagy csak egy zárt csoporton belül) attól függ, hogy milyen sok emberre számítunk, mennyi kapacitásunk van a jelentkezők szűrésére és felkészítésére és milyen mértékben bizalmi az a feladat, amit el fognak végezni.

A felhívást közzé lehet tenni email cím megadásával, de kérhetjük a jelentkezőket arra is, hogy töltsenek ki egy online ürlapot, ahol részletesebb információt tudunk tőlük kérni a tapasztalataikról, motivációikról, időbeosztásukról stb. Itt fontos, hogy mindig betartsuk az adatvédelmi előírásokat és megkapjuk a felhatalmazást arra, hogy kezeljük a jelentkezők adatait.

Mielőtt bármibe bevonjuk őket, a jelentkezőkkel mindig vegyük fel a kapcsolatot, ha lehetséges, telefonon, ha nem, emailben. Ez a személyes kapcsolatfelvétel segít abban, hogy mind a szervezet, mind a jelentkező el tudja dönteni, hogy valóban akarnak-e együtt dolgozni, illetve minden kérdést, dilemmát is tisztázni lehet. 


\section{Önkéntesek bevonása}

Együttmúködés esetén az új önkéntest érdemes bekapcsolni azokba a kommunikációs platformokba, ahol megismerkedhet a többi önkéntessel és bekapcsolódhat a munkába. Erre használhatunk levelezőlistát, zárt Facebook-csoportot vagy bármely más online platformot, ami a közösségünk számára megfelel.

Ahhoz, hogy mindenki egyenrangúan részt tudjon venni a csoport munkájában és el tudja dönteni, hogy mely feladatokat tudja vállalni, illetve miben szeretne részt venni, érdemes egy rövid útmutatót írni minden újonnan csatlakozónak, ami a közösség múködését mutatja be. Ide tartozik például az, hogy ki miért felelős, hogyan lehet feladatot vállalni, milyen szabályokat kell betartani.

Speciális tudást igénylő feladatoknál érdemes online képzést tartani, ahol át tudjuk adni a feladatok elvégzéséhez kapcsolódó tudást és meg tudjuk beszélni a részletekre vonatkozó kérdéseket, információkat az önkénteseknek. Minden ilyen képzéshez készüljön sorvezető és jegyzet is, hogy akinek technikai problémája van, az is tudja követni akár utólag is az eseményt.

\section{Csapatépítés és közös tanulás}

Ahogyan a személyes szervezés során, úgy az online szervezésben is szükség van arra, hogy senki ne érezze magát egyedül és közösséget építsünk. Így tudjuk elérni azt, hogy ne csak pillanatokig tartson az emberek lelkesedése vagy elkötelezettsége, hanem hosszú távon is tudjunk közösen dolgozni és fejleszteni a tevékenységünket.

A csapatépítés fontos eleme a személyre szabott odafigyelés. Ismernünk kell az önkénteseinket, nem szabad őket arctalan tömegként kezelni. Jó, ha tudjuk, hogy ki milyen munkát végez szívesen, milyen az időbeosztása, mi az, amit nem vállal szívesen, egyedül vagy másokkal szeret-e dolgozni stb. Így a feladatok elosztásánál van arra lehetőség, hogy ha nem is mindenki mindig azt csinálja, ami a kedvenc elfoglaltsága, de azért az idő jelentős részében olyan dolgokat csináljon, ami nemcsak hasznos, de örömet is okoz neki.

Fontos része a munkának a visszajelzés is, ami az online múködés során talán még fontosabb, mert kevésbé tudunk személyes gesztusokat tenni egymás felé, nehezebb egymással kedvesnek lenni. Érdemes rendszeresen összegzést készíteni az elvégzett feladatokról, az önkéntesek és a segítettek számáról. Az önkéntesektől ehet kérni visszajelzést az egy-egy nap vagy egy-egy nagyobb közös vállalkozás végén, hogy mindannyian közösen tudjunk tanulni és fejlődni. Ha valaki nagy kihívást győzött le, akkor őt akár egyénileg is érdemes kiemelni, de 
figyeljünk arra, hogy senki ne legyen túlságosan kiemelve és ne legyen senkinek olyan érzése, hogy bizonyos feladatok vagy önkéntesek értékesebbek lennének, mint mások.

A csapatépítés része a közös tanulás is: teremtsünk teret arra, hogy a különböző hátterú emberek találkozzanak, véleményt cseréljenek, levonják a közös tanulságokat. Egy önkormányzat esetében különösen termékeny tud lenni, ha szociális szakemberek, önkéntesek és hivatalnokok is közösen tanulnak, eszmét cserélnek egymással és ezáltal formálják egymás munkáját és világképét.

\section{Az önkéntesek mentális támogatása}

A távolságtartás és a sok online kommunikáció idején talán még a szokásosnál is fontosabb az önkéntesek és szervezők mentális és lelki támogatása. A „Vigyázzunk magunkra és másokra!” felhívás itt is érvényes. Érdemes olyan informális, ventilálásra, tapasztalatcserére, ötletelésre és visszajelzésre alkalmas online találkozókat szervezni, ahol a napirend kevésbé kötött és mindenki szabadon hozzá tud szólni. Lehet nagyobb, strukturáltabb online önkéntes találkozókat szervezni és ha szükséges, akkor érdemes pszichológusok és/vagy szupervizorok segítségét kérni, akik egyénileg vagy közösségi szinten is tudnak segíteni a kiégés megelőzésében, valamint a bizonytalanság, feszültség és frusztráció kezelésében.

\section{Külföldi önkéntesek koordinálása}

Józsefváros egy multikulturális hely, ami az önkénteseink összetételében is tükröződik. A Covid-19 világjárvány idején nagy örömünkre több külföldi önkéntesünk is volt, akik úgy gondolták, tevékenyen vennének részt a védekezésben, segítve ezzel a kerületet, ahol élnek, így abban is szereztünk némi tapasztalatot, hogy mi a teendő, ha a segítők és a segítettek nem feltétlenül beszélnek közös nyelvet. Általános jellegű tanácsot nehéz adni, hiszen sok minden függ a rendelkezésre álló erőforrásoktól és feladatoktól, ezért itt inkább saját gyakorlatunkat mutatjuk be.

Eleinte a veszélyhelyzeti, közérdekú plakátok kiragasztásába tudtuk bevonni a magyarul nem beszélő önkénteseket. A kerület társasházait járva minden esetben egy külföldi és egy angolul beszélő magyar önkéntes közösen ment plakátolni. Ezt a biztonsági megfontolások mellett az is indokolta, hogy a kerület társasházaiba nem mindig könnyű bejutni, és sokszor szükség van magyar nyelvű kommunikációra. Ezen kívül a tartós élelmiszerek csomagolásába is be tudtuk vonni a külföldi önkénteseket, ahol óriási segítséget jelentettek, majd egy későbbi szakaszban - ismét egy magyar párral - a melegétel (ebéd) napi szintű kiszállításában tudtak segíteni, 
közösen a gépjármúvet és sofőrt adó kerületi közterületi felügyelettel. A külföldi önkéntesek támogatásában egy angolul folyékonyan beszélő önkéntes segítette a Közösségi Részvételi Iroda önkéntes koordinátorát.

\section{TECHNIKÁK AZ ÖNKÉNTESEK SZERVEZÉSÉHEZ A COVID-19 JÁRVÁNY ALATT}

\section{A biztonság mindenekelött}

A pandémiás helyzet alatt különösen fontos, hogy vigyázzunk mind az önkéntesekre, mind pedig azokra, akiknek segítünk, ezért minden önkéntesnek kötelező betartania a higiéniás előírásokat, amelyet nyomtatva és online is elérhetővé kell tenni mindenki számára. Ami a legfontosabb tanácsunk mindenkinek, aki járvány alatt vállal önkéntes segítést: bárhova megy, mindig legyen nála kesztyű, maszk és kézfertőtlenítő! A mi szlogenünk ez volt Józsefvárosban: „A te maszkod engem véd, az én maszkom téged. Vigyázzunk egymásra!”

\section{Feladatvállalás az önkéntes csoportban}

A Közösségi Részvételi Iroda létrehozott egy Facebook-csoportot kifejezetten az önkormányzatnak segítő önkéntesek részére. A beérkező kéréseket, feladatokat a koordinátor mindig ebben a csoportban posztolja, hogy mindenki egyszerre értesüljön és így, lehetősége legyen részt venni mindenben, amiben szeretne. Lehetnek természetesen mindenhol olyan önkéntesek is, akik nincsenek fenn a Facebookon, velük a koordinátor messengeren, emailben vagy telefonon tudja tartani a kapcsolatot.

Mivel érzékeny, személyes információkat nem szabad megosztani ilyen széles körben, az egyes vállalható feladatok esetén a koordinátor minimális személyes információt tesz közzé egy-egy tennivalóval kapcsolatban a Facebook-csoportban. Legtöbbször egy utcanevet és feladatot látnak az önkéntesek (Baross utca: gyógyszerkiváltás; Magdolna utca: kutyasétáltatás). A pontosabb információkat akkor kapja meg az önkéntes, ha felhívja közvetlenül a koordinátort vagy ha elvállalja a feladatot. Tudomásunk szerint több településen ugyanezt az információcserét különböző applikációk segítségével oldották meg, azonban Józsefvárosban tökéletesen megfelelt ez a szintű technológia a munka megszervezéséhez.

$A z$ összetettebb vagy rendszeresen visszatérő feladatokhoz a koordinátornak érdemes online elérhető excel táblákat készíteni, ahova jó előre be lehet írni, ha valaki szívesen segítene (ilyen lehet például, amikor egy üzletbe vagy pékségbe heti vagy akár napi rendszerességgel lehet menni az adományokért). 


\section{ÖNKÉNTES FELADATOK A COVID-19 JÁRVÁNY IDEJÉN JÓZSEFVÁROSBAN}

\section{Józsefvárosi zöld szám}

A józsefvárosi zöld számot kifejezetten a koronavírus kapcsán hoztuk létre, hogy mindenki ingyenesen tudjon segítséget kérni az önkormányzattól. Azóta nagy örömünkre, a zöld szám már beépült a Józsefvárosi Önkormányzat hivatalos szolgálatásai közé. A pandémiás helyzet elején (2020. március-június között) havonta közel ezer hívást is kaptunk, de azóta kiegyensúlyozottabbá vált a helyzet és havi 150-300 hívás érkezik hozzánk. A zöld számon az önkormányzat munkatársai és önkéntesek is vállalnak ügyeletet.

Arra, hogy a zöld számra beérkező kérésekkel és kérdésekkel mi történik, kidolgoztunk egy szakmai protokollt, amiről minden ügyeletes képzést kap. Az ügyeletesek tapasztalatait és a protokoll alkalmazását érdemes rendszeresen átbeszélni, értékelni és fejleszteni. A mi esetünkben ennek a terepe egy kifejezetten erre a célra kialakított Facebook-csoport, illetve a havi rendszerességgel tartott ún. zöld teaház volt.

\section{Plakátozás}

A pandémia alatt megszámlálhatatlanul sok plakátot raktunk ki a kerületben, mert a pontos tájékoztatásnak kulcsszerepe volt a védekezésben. A Közösségi Részvételi Iroda munkatársai és önkéntesei tervezték és nyomtatták a plakátokat mindenféle méretben (legtöbbször A3A4-es méret, színes). Vírushelyzeten kívül plakátot csak a házak kapukon belüli hirdetőtábláira szabad ragasztani, de a vírushelyzet alatt a házak bejáratára, üzletekbe és közterületre is raktunk ki plakátokat, hogy minél több emberhez eljussanak a létfontosságú információk. Fontos, hogy a plakátokat mindig csak az adott felület megrongálása nélkül szabad kirakni. Plakátozáskor azt javasoljuk, hogy mindig legyen nálunk fertőtlenítőszer, celluxtépő és pót ragasztószalag-tekercsek, mert ezek nélkül sokkal lassabban megy a munka. Ezt a munkát nem igazán praktikus kesztyüben csinálni, ezért járványhelyzetben inkább a gyakori kézmosás és a fertőtlenítés ajánlott.

Mi Józsefvárosban hat különböző nyelvre fordítottuk le az általános tájékoztató plakátokat, ami nagyon hasznosnak bizonyult ahhoz, hogy a nem magyar anyanyelvű szomszédaink is minden fontos információról értesüljenek. A fordításokat is természetesen önkéntesek készítették, akiket helyi civil szervezetek és más önkéntesek segítségével találtunk meg. 


\section{Bevásárlás időseknek, karanténban lévőknek, betegeknek}

A járványhelyzetben nagyon sokan kértek tőlünk segítséget a bevásárlásban vagy azért, mert idősebb lakosként nem mertek az utcára menni vagy azért, mert karanténban voltak vagy pedig azért, mert annyira betegek voltak, hogy nem tudták magukat egyedül ellátni. A bevásárlással kapcsolatban a következő tanácsokat fogalmaztuk meg saját önkénteseinknek, amik annyira beváltak, hogy másoknak is szívesen ajánljuk.

Miután megkapjuk a koordinátortól a feladatot, mindenképpen érdemes felvenni a kapcsolatot az ügyféllel: mutatkozzunk be és jelezzük neki, hogy mikor fogunk érkezni. Fontos előre ellenőrizni, hogy helyesek-e a zöld szám által számunkra közvetített információk, mint például a kapucsengő száma, a kapukód stb. Arról is meg kell bizonyosodni szóban is, hogy van-e elég készpénz az ügyfélnél a vásárláshoz. Ilyenkor érdemes megkérdezni az ügyfelet arról is, hogy mekkora mennyiséget szeretne, honnan, van-e elegendő táskája, szatyra hozzá. Végül pedig egyezzünk meg egy mindkettőnknek megfelelő időpontban!

A helyszínre való kiérkezéskor közösen ellenőrizzük a bevásárlólistát, és ha valami nem egyértelmú, mindenképpen kérdezzünk rá. Ha úgy gondoljuk valamiről, hogy hiánycikk, kérdezzük meg, hogy hozzunk-e helyette valamit. Ha nagy mennyiséget szeretne vásárolni az ügyfél, kérjünk fémszázast a bevásárlókocsi használatához.

Alapesetben az ilyen vásárlások során készpénzzel fizetünk és a készpénz átvételéről és visszaadásáról elismervényt írunk az ügyféllel. Sok esetben, ha már bizalmi viszony alakult ki az önkéntes és az ügyfél között, ez elhagyható, de mindenki nyugalma és biztonsága érdekében inkább érdemes ezt betartatni.

Fontos még tudatosítani az ügyfelekben, hogy ez a fajta segítség nem egy komplett nagybevásárlás, és önkénteseink tényleg csak a legszükségesebbeket tudják elhozni (nem cipelünk például kartonszámra ásványvizet). Nagyobb bevásárlásra érdemes javasolni azokat a nagyobb cégeket, amik házhoz is szállítanak.

Fontos, hogy ha olyan embernek kell segíteni, aki hatósági karanténban van vagy tudott róla, hogy koronavírus fertőzött, akkor dupla kesztyű és dupla távolságtartás ajánlott. Ilyen esetben bármit csak borítékban vagy múanyag zacskóban vegyünk át vagy adjunk oda.

\section{Kutyasétáltatás}

Egy időben több megkeresést kaptunk elsősorban idős emberektől, akiknek arra volt szüksége, hogy a kutyájukat elvigyük sétálni. Idővel azonban egyre több civil szervezet kezdett el segíteni 
az egész országban a karanténba szorult emberek kutyáinak ellátásában és sétáltatásában, így ilyen megkeresés később kevesebb érkezett. Tapasztalataink szerint az ilyen jellegű segítségnyújtáskor érdemes pontosan kijelölni a segítség jellegét és kereteit, ezzel védve az ügyfeleket és a segítóket is.

Mi Józsefvárosban az alábbi szempontokat fogalmaztuk meg saját magunk és ügyfeleink számára, amik másoknak is hasznosak lehetnek:

- napi kétszer visszük a kutyát, reggel kb. 10 körül és délután 4-5 körül,

- kutyaürülék zacskót mindig viszünk magunkkal, kb. 3-4 db legyen nálunk,

- minden kutyának más a mozgásigénye, ezt próbáljuk figyelembe venni a sétáltatáskor,

- minden héten hétfőn hívjuk fel a kutya gazdáját, hogy azon a héten mikor tudjuk vinni a kutyust.

\section{Szociális támogatás igénylése}

A COVID-19 járvány ideje alatt a Józsefvárosi Önkormányzat egy új pénzügyi támogatást tett elérhetővé kifejezetten a vírus által érintett emberek számára. A kérvényt emailben és személyesen is le lehetett adni, önkéntesként mi a hivatali leadásnál segédkeztünk. A segítségnek ez a fajtája precedens nélküli a kerületben - és tudomásunk szerint más településeken is, - így tudásunkat a konkrét tapasztalatok összegzésével osztjuk meg.

Az első segítő alkalom előtt mindenkinek részt kellett vennie egy a Közösségi Részvételi Iroda által tartott képzésen és el kellett olvasni az illetékes szakemberek által erre a célra összeállított anyagokat, ami nagy segítségnek bizonyult, amikor élesben kellett segíteni az embereknek.

Személyesen leginkább azok jöttek leadni a támogatás igényléséhez szükséges iratokat, akiknek nem volt lehetőségük ezt megtenni elektronikus formában. Gondot okozhat például, hogy

- több ügyfél nem tud írni (ebben az esetben kapacitástól függően segítettünk nekik leírni a papírra, amit mondanak),

- az ügyfél idős és nem tudja használni a számítógépet (ilyenkor is segítünk kitölteni/átnézni az iratokat),

- az ügyfél nem hallott róla, hogy online is be lehet küldeni az igénylést (ilyenkor erre bíztattuk őket, mert gyorsabb és egyszerúbb, ha nem papíron kerül be a hivatalba), 
- az ügyfélnek nehezére esik a hivatalos dokumentumok kitöltése, vagy úgy értékeli, hogy az a biztos, ha személyesen adja le (ilyenkor is segítünk átnézni/kitölteni).

A helyszínen az önkéntesek feladata az volt, hogy tájékoztassák a sorban állókat, ha valamilyen információra van szükségük (pl. a kérdések értelmezésében), segítsenek kitölteni az igényléshez szükséges nyomtatványt, illetve igény szerint ellenőrizzék a már kitöltött nyomtatványt és ellenőrizzék, hogy minden papírt csatoltak-e hozzá.

Fontos előírás volt, hogy az önkéntes csak segíteni tud, de semmit nem csinálhat meg az ügyfelek helyett. Tanácsolni tud, de döntést hozni nem és mindezt egyértelmúen szükséges kommunikálni az ügyfelek felé.

Tudjuk, hogy mindenkinek nehéz, ha sokan állnak sorban. Viszont akik sorban állnak, valószínúleg igen nehéz helyzetben vannak és ezért feszültebbek, érzékenyebbek és ingerlékenyebbek lehetnek az átlagnál. Ami a legfontosabb: legyünk mindig és mindenkivel türelmesek, kedvesek és megértőek!

\section{Ételcsomagolás}

A járvány ideje alatt többször segítettünk a Józsefvárosi Szociális Szolgáltató és Gyermekjóléti Központnak, hogy a kapott adományokból szállításra kész csomagokat állítsunk össze rászoruló családoknak, időseknek. Összességében ez a feladat nem nehéz és maximum 1-2 órát vesz igénybe, így jó induló feladat lehet új önkénteseknek is.

Az egészségügyi előírások betartásával maszkban és kesztyűben kétféle csomagot állítottunk össze: tisztasági- és élelmiszer csomagot. Mindkettőben az volt, amilyen adomány éppen érkezett. A tisztasági csomag tartalma általában mosópor, hypo, szappan, sampon; az élelmiszer csomagé olaj, tészta/rizs, zacskós leves, cukor, liszt, fúszer, majonéz volt. Az elkészült csomagokat végül további önkéntesek juttatták el azokhoz, akik a csomagokat a zöld számon vagy a családsegítőben igényelték.

\section{Ételszállitás}

A járvány ideje alatt azzal is segítettük a kerületi családsegítő központ munkáját, hogy kész főtt ételt (ebédet) juttattunk el, előre megadott címekre. A helyi gondozóház konyháján elkészítették az ételt, becsomagolták, és átadtak nekünk egy címlistát, ahova ki kellett ezeket szállítani. Általában két önkéntes ment egyszerre és egy közterület-felügyelő szolgálati autóval szállított minket és a csomagokat a megadott címekre. Ez a fajta közös munka az önkormányzat hivatásos állománya és az önkéntesek között fontos pozitív tapasztalatok 
forrása volt, ami erősítette a bizalmat és a szolgáltatások színvonalát is. Egy-egy kiszállítás a címek számától függően összesen maximum 1,5-2 órát vett igénybe.

Ennél a feladatnál a legfontosabb tanulság az volt, hogy az információmegosztásnak kulcsszerepe van. A gördülékeny menetet az segíti leginkább, ha megosztjuk egymással, mi történt előző nap, volt-e valahol probléma, és ha igen, mi volt az, és mi volt a megoldása. Nagyon sok időt tud mindenki megtakarítani magának és a társainak is az információ megosztással.

\section{Gyógyszerkiváltás}

Nagy gondot okozott a járvány elején az idősebb vagy karanténba kerülő lakóknak, hogyan hozzájussanak a receptre felírt gyógyszerekhez. Szerencsére viszonylag hamar született egy kormánydöntés, miszerint a név és TAJ-szám bemondásával ki lehet váltani mások számára is a megfelelő gyógyszereket.

Hamar kitapasztaltuk, miként lehet ezt jól csinálni, mikor van csúcs a patikákban, hogyan fizessünk és elég-e, ha telefonon egyeztetünk az ügyféllel vagy személyesen kell odamenni. Ez utóbbi választása nem mindig túnt túl praktikusnak, viszont sok idős embernek az a néhány perc lehet az egyetlen kapcsolata a külvilággal, amíg odaadta a listát és a készpénzt, ezért nem mindig érdemes megspórolni.

A gyógyszerek kiváltásának előzménye természetesen a gyógyszerek felíratása, hiszen sok idős nem tudott elmenni az orvoshoz a papír alapú receptekért, az e-recept használata pedig sajnos még mindig sok ügyfélnek gondot okozott. Ennek elintézéséhez praktikus volt kideríteni a háziorvos nevét vagy az asszisztens elérhetőségét, akikkel egyeztetni lehetett az igényeket. Érdemes volt többször leegyeztetni az ügyféllel is, hogy pontosan milyen gyógyszereket szed, amiket egy kis listára fel is írhatott. Nálunk jól bevált, hogy egy otthonról dolgozó önkéntes elintézte a felíratást, jelzett a koordinátornak és ő már így adta ki a „munkát” az önkéntesnek.

\section{UTÓsZÓ}

A pandémiás helyzet nagy lökést adott a Józsefvárosi Önkormányzatban nemcsak az önkéntesség rendszerének kialakításához, de ahhoz is, hogy a hivatal vezetése elismerje az önkéntesség és az önkéntesek jelentőségét és hasznosságát. A 2020 márciusa és júniusa között szerzett tapasztalatok alapján a Közösségi Részvételi Iroda kidolgozott egy önkéntes stratégiát, amely négy területet azonosított az önkéntesek bevonására: zöld szám, segítés, 
közösségi csoport és tájékoztató csoport. A négy területre négy munkacsoportot alakítottunk, amelyekben az önkéntesek folyamatos kapcsolatban vannak egymással, közösen hajtanak végre feladatokat és képzik magukat tovább. Az önkéntes rendszer múködésében a koronavírus alatt szerzett munkamódszereket folytatjuk és fejlesztjük tovább. A Józsefvárosi Önkormányzat munkáját 2021 májusában továbbra is kb. 30-40 önkéntes segíti folyamatosan. Józsefvárosban önkénteskedni nagyon jó, érdekes, színes, néha nehéz, de legtöbbször szívmelengető feladat. Nagyon sok érdekes és értékes emberrel lehet megismerkedni, sőt, ami még jobb: segíteni nekik a koronavírus okozta nehéz helyzetben és azon túl is. Mi úgy tapasztaltuk, hogy a végén szinte mindenki többet kapott az önkénteskedéstől, mint amit beletett - sokkal többet, mint az elején gondolta volna! Ha valakinek megjön a kedve a segítéshez, várjuk szeretettel önkéntesként Józsefvárosban, a Közösségi Részvételi Iroda elérhetőségeinek egyikén. ${ }^{6}$

\footnotetext{
${ }^{6}$ https://jozsefvaros.hu/onkormanyzat/iroda/33-93

https://jozsefvaros.hu/szoljon-bele

https://www.facebook.com/reszveteliiroda/
} 